\title{
PENGARUH GAYA KEPEMIMPINAN, MOTIVASI KERJA, DAN DISIPLIN KERJA TERHADAP KINERJA KARYAWAN KANTOR NOTARIS PANAM
}

\author{
Jeli Nata Liyas \\ Jurusan Manajemen Fakultas Ekonomi STIE RIAU \\ jaznatan@yahoo.co.id
}

\begin{abstract}
This study aims to examine and analyze the influence of leadership style, motivation and discipline to employee performance Notary in Pekanbaru Tambusai lord street. Data collected through questionnaires and conducted on 71 employees who are in the way Notary Tambusai lord Pekanbaru. Analysis of the data in this study using SPSS version 16. In this study did not use sampling techniques since the sample studied is the whole of the population, or so-called census data and testing techniques used in this study include validity, reliability with Cronbach Alpha, classic assumption test and multiple linear regression analysis, to test and prove the hypothesis penelitian.Hasil analysis shows that the leadership style of significant positive effect on employee performance, motivation of no effect and no significant effect on employee performance and discipline significant positive effect on employee performance.
\end{abstract}

Keywords: Leadership Style, Work Motivation, Work Discipline And Employee Performance

\begin{abstract}
Abstrak
Penelitian ini bertujuan untuk menguji dan menganalisis pengaruh gaya kepemimpinan, motivasi dan disiplin kerja terhadap kinerja karyawan Notaris yang ada di Panam. Pengumpulan data dilakukan melalui penyebaran kuesioner dan dilaksanakan pada 71 orang karyawan Notaris yang ada di Panam. Analisis data pada penelitian ini menggunakan bantuan SPSS versi 16. Dalam penelitian ini tidak digunakan teknik sampling karena sampel yang diteliti adalah keseluruhan dari populasi yang ada atau disebut dengan sensus dan teknik pengujian data yang digunakan dalam penelitian ini meliputi uji validitas, uji reliabilitas dengan Alpha Cronbach, uji asumsi klasik dan analisis regresi liner berganda, untuk menguji dan membuktikan hipotesis penelitian. Hasil analisis menunjukkan bahwa gaya kepemimpinan berpengaruh positif signifikan terhadap kinerja karyawan, motivasi tidak berpengaruh dan tidak signifikan terhadap kinerja karyawan dan disiplin kerja berpengaruh positif signifikan terhadap kinerja karyawan.
\end{abstract}

Kata Kunci: Gaya Kepemimpinan, Motivasi Kerja, Disiplin Kerja Dan Kinerja Karyawan 


\section{PENDAHULUAN}

Sumber daya manusia merupakan sumber daya yang paling penting dalam memenangkan persaingan pada setiap organisasi.Apabila organisasi tidak dapat mengelola sumber dayanya dengan baik, maka efektfitas organisasi tidak dapat tercapai atau bahkan bisa menimbulkan kerugian dan gulung tikar pada organisasi tersebut. Banyak faktor yang dapat mempengaruhi dalam pengelolaan sumber daya manusia sesuai dengan perkembangan dan kemajuan teknologi yang terjadi saat ini.

Dalam melaksanakan kegiatannya, setiap organisasi yang bergerak dibidang pabrikan maupun jasa akan berusaha untuk mencapai tujuan yang telah ditetapkan pada setiap organisasinya. Keberhasilan organisasi tidak hanya tergantung pada perkembangan jaman yang mengandalkan keunggulan teknologi,dana operasional yang tersedia, maupun sarana dan prasarana yang dimiliki, melainkan juga tergantung pada kemampuan sumber daya manusianya. Kualitas dari kinerja manusia merupakan faktor penentu untuk mewujudkan tujuan dari organisasi tersebut.

Notaris/PPAT adalah Pejabat Umum yang berwenang untuk membuat Akta Otentik mengenai semua perbuatan, perjanjian, surat kuasa dan ketetapan yang diharuskan oleh peraturan perundangundangan dan/atau yang dikehendaki oleh yang berkepentingan untuk dinyatakan dalam akta otentik, menjamin kepastian tanggal pembuatan akta, menyimpan akta, memberikan grosee, salinan dan kutipan akta, semuanya itu sepanjang pembuatan akta-akta itu tidak juga ditugaskan atau dikecualikan kepada pejabat lain atau orang lain yang ditetapkan oleh Undang-undang.

Kinerja Karyawan adalah hasil kerja secara kualitas dan kuantitas yang dicapai oleh seorang pegawai dalam melaksanakan tugasnya sesuai dengan tanggung jawab yang diberikan kepadanya (Anwar Prabu Mangkunegara 2006:20). Kinerja karyawan adalah salah satu hal yang berperan sebagai faktor penentu keberhasilan tujuan suatu organisasi. Selain mesin atau alat-alat lainnya, karena karyawan yang langsung bersentuhan dengan pekerjaan masingmasing agar dapat untuk memberikan produktivitas sesuai dengan keinginan yang diharapkan.Untuk itu kinerja karyawan harus selalu diperhatikan dengan memperbaiki keburukan atau kebiasaan-kebiasaan yang kurang mendukung dalam pencapaian kinerja. Dengan kurang maksimalnya kinerja dari karyawan maka dapat dikatakan bahwa tujuan organisasi masih belum tercapai, karena masih rendahnya tingkat kinerja karyawan.

Salah satu cara untuk menilai kebehasilan suatu organisasi yaitu dengan melalui penilaian. Penilaian kinerja sangat penting, karena dengan melalui penilaian kinerja dapat diketahui seberapa tepat karyawan dalam menjalankan tugasnya. Ketepatan karyawan dalam menjalankan tugasnya akan sangat berpengaruh terhadap pencapaian kinerja organisasi secara keseluruhan. Selain itu, hasil penilaian kinerja karyawan akan memberikan informasi penting dalam proses pengembangan pegawai yang nantinya diharapkan memberikan pelayanan secara baik kepada publik atau masyarakat maupun internal mereka. Namun sering kita jumpai penilaian dilakukan tidak tepat dan ketidaktepatan itu disebabkan oleh beberapa faktor, yaitu diantaranya adalah ketidakjelasan makna kinerja yang diimplementasikan, ketidakpahaman karyawan mengenai kinerja yang diharapkan, ketidakakuratan instrumen penilaian kinerja, dan ketidakpedulian pimpinan organisasi dalam pengelolaan kinerja, sehingga hal-hal tersebut telah membudaya dalam organisasi.

Penilaian kinerja dapat diperoleh 
dengan cara memperhatikan faktor gaya kepemimpinan, motivasi kerja dan disiplin kerja dalam suatu organisasi agar tersotirnya pekerjaan maupun kinerja agar pencapaian produktivitas yang dihasilkan lebih optimal.

Menurut Kartini Kartono (2008:34) "Gaya kepemimpinan adalah sifat, kebiasaan, tempramen, watak dan kepribadian yang membedakan seorang pemimpin dalam berinteraksi dengan orang lain". Setiap pemimpin memiliki sifat, kebiasaan, watak dan kepribadian yang khas dalam memimpin organisasi. Pemimpin harus memiliki sifat kepribadian yang baik agar menjadi panutan bagi bawahannya untuk mentaati dan mau bekerjasama dengan rasa tanggung jawab yang tinggi untuk mencapai tujuan dari organisasi. Pemimpin yang acuh tak acuh terhadap kinerja karyawannya, akan menyebabkan karyawan bertindak seenaknya saja dan hasil dari kinerja tersebut akan sangat buruk bagi organisasi.

Dalam melakukan kegiatan operasionalnya, organisasi membutuhkan seorang pemimpin yang disiplin, memiliki kepribadian yang baik, mempunyai pengetahuan dan memiliki keterampilan yang akan memberikan contoh yang baik bagi pegawainya. Pemimpin harus memberikan perhatian yang lebih terhadap pegawai, agar kinerja dari karyawannya dapat meningkat. Dari pengamatan awal dilapangan sementara dijumpai sikap pemimpin yang kurang perduli dan kurang memperhatikan apapun yang terjadi pada karyawannya. Pemimpin juga bersikap kurang tegas dan kurang memberikan penjelasan rencana yang akan dilakukan dengan pegawai sehingga kinerja pegawai menjadi menurun. Disamping itu sifat pemimpin yang kurang disukai oleh pegawai adalah di waktu tertentu pimpinan memberikan pekerjaan yang melebihi kapasitas dan harus harus selesai dalam jangka waktu yang sudah ditentukan sehingga mengharuskan pegawai mengerjakannya sampai selesai meskipun sudah diluar jam kerja yang telah ditentukan.

Dari uraian tersebut, peneliti berargumen bahwa seorang pemimpin yang perduli kepada karyawannya akan membuat karyawan merasa dihargai dan karyawan akan lebih berkomitmen terhadap organisasi sehingga muncul rasa memiliki terhadap organisasi tempatnya bekerja.

Selain gaya kepemimpinan, organisasi juga harus memperhatikan mengenai bagaimana menjaga dan mengelola motivasi karyawan dalam bekerja agar selalu tinggi dan fokus pada tujuan organisasi. Motivasi karyawaan harus dijaga karena motivasi yang diberikan organisasi kepada karyawan dapat menunjang setiap karyawannya untuk melakukan suatu hal yang menguntungkan organisasinya.

Robbins (2009:110) mendefinisikan motivasi sebagai proses yang ikut menentukan intensitas, arah, dan ketekunan individu dalam usaha mencapai sasaran. Motivasi sebagai proses yang bermula dari kekuatan dalam hal fisiologis dan psikologis atau kebutuhan yang mengakibatkan perilaku atau dorongan yang ditujukan pada sebuah tujuan atau insentif. Motivasi pada kantor Notaris/PPAT masih tergolong rendah. pada kantor Notaris tidak ada jenjang karir yang jelas karena kantor notaris adalah jasa perorangan yang dipimpin hanya oleh satu orang saja. Karyawan juga tidak mendapatkan asuransi kecelakaan maupun jaminan hari tua sehingga menyebabkan menurunnya kualitas kerja dari para karyawan.

Dalam organisasi, motivasi harus mendapat perhatian yang serius bagi manajemen sumber daya manusianya. Organisasi pada masa sekarang harus menjadikan karyawan sebagai aset terpenting untuk kelangsungan organisasinya. Perusahaan diharapkan dapat memenuhi kebutuhan karyawannya dan membuat 
karyawan merasa nyaman agar kerjasama antara karyawan dan organisasi bisa mencapai visi dan misi yang telah ditentukan. Secara umum untuk memberikan motivasi kepada karyawan, organisasi dapat memberikan berupa fasilitas yang disediakan, tingkat kesejahteraan yang memadai, jenjang karir yang jelas, peluang aktualisasi diri, kenyaman dan keamanan dalam bekerja, jaminan hari tua dan lain lain.

Selain gaya kepemimpinan dan motivasi kerja, kedisiplinan juga mempengaruhi kinerja dari karyawan itu sendiri. Menurut Buhler (2007: 216-218) Disiplin benar-benar memainkan peran penting dalam membentuk tingkah laku. Seperti halnya penghargaan yang efektif dalam memotivasi orang, disiplin jika digunakan secara tepat maka dapat samasama efektif. Disiplin berpengaruh terhadap tanggungjawab dalam menyelesaikan tugas yang diberikan. Sehingga apabila disiplin sudah terpenuhi maka akan menimbulkan suatu kepuasan dan hasil yang baik dalam organisasi.

Permasalahan yang sering teradi oleh karyawan dalam menjalankan disiplin pada kantor Notaris diPanam adalah masalah disiplin waktu. Disiplin terhadap waktu seperti pegawai sering datang terlambat, pulang sebelum waktunya, adanya pegawai yang tidak tepat waktu dalam menyelesaikan pekerjaannya, menambah waktu libur, dan bahkan menitipkan absen kepada temannya. Dari permasalahan tersebut yang terjadi maka perlu ada penerapan disiplin dari pihak karyawan dan menerapkan sanksi agar para karyawan dapat menjalankan disiplin dalam melakukan pekerjaannya.
Organisasi harus memperlakukan karyawan secara adil dan konsisten. Setiap perilaku penyimpangan yang dilakukan oleh setiap karyawan harus mendapat perlakuan yang sama agar tidak menimbulkan kecemburuan sosial antara karyawan yang satu dengan karyawan yang lainnya. Kunci bagi disiplin yang efektif adalah mengomunikasikan kebijakan sejak awal. Para karyawan harus benar-benar memahami kebijakan yang ada pada organisasi tersebut. Bahkan, organisasi perlu mencetak dan memberikan 'Buku Pedoman Karyawan' kepada semua karyawan. Proses disiplin sangat penting untuk ditulis, diterima dan dipahami oleh setiap karyawan. Tetapi sayangnya pada kantor Notaris/PPAT di pekanbaru tidak banyak yang memberlakukan 'Buku Pedoman Karyawan' tersebut. Peraturan organisasi hanya berdasarkan kepada kebiasaan yang telah diberikan atasan kepada karyawan senior sehingga menyebabkan kurangnya kedisplinan bagi setiap karyawan.

Dalam pengamatan awal pada Kantor Notaris diPanam terjadi dilapangan ketidaktepatan waktu dalam menyelesaikan tugas, meninggalkan pekerjaan yang belum siap dan pandangan masyarakat atau publik penurunnya produktivitas karyawan dalam memberikan pelayanan masyarakat. Dengan kurang baiknya pelayanan karyawan terhadap masyarakat tersebut, diperlukan adanya evaluasi dan pengawasan dari atasannya. Kurang optimalnya kinerja karyawan terhadap masyarakat, diperlukan evaluasi dan tindakan yang konkrit dari pimpinan untuk melakukan evaluasi dan pengawasan terhadap kinerja karyawan dalam bentuk survey kepuasan masyarakat. 
Tabel 1

Target dan Realisasi penyelesaian balik nama sertipikat di kantor Notaris tahun 2016

\begin{tabular}{ccc}
\hline Tahun & Target & Realisasi \\
\hline 2013 & 100 Hari & 100 Hari \\
2014 & 100 Hari & 90 Hari \\
2015 & 100 Hari & 110 Hari \\
2016 & 100 Hari & 120 Hari \\
2017 & 100 Hari & 180 Hari \\
\hline
\end{tabular}

Sumber: Kantor Notaris H Masrijal, SH, Amd, MH, MKn dan Ilawati, SH, MKn 2018

Pada Tabel 1.1 dapat dilihat bahwa hasil kinerja Notaris di Panam menunjukkan kondisi kinerja karyawan yang naik turun dalam pencapaian perencanaan program kegiatan yang dilakukan. Pada tahun 2011 menunjukkan bahwa kinerja karyawan dapat memenuhi waktu realisasi yang telah ditentukan. Pada tahun 2012 hasil kinerja karyawan mengalami peningkatan dimana hasil lebih cepat daripada waktu yang telah ditentukan. Sedangkan pada tahun 2013 sampai dengan tahun 2015 hasil kinerja karyawan mengalami penurunan dimana waktu pencapaian tidak sesuai target waktu yang ditentukan. Ini menunjukkan hasil kinerja karyawan kurang maksimal, tidak efektif dan efisiensi dalam pencapaian target yang ditentukan.

Dalam penelitian Harlie (2012) dalam jurnal aplikasi manajemen dengan judul penelitian "Pengaruh Disiplin Kerja, Motivasi dan Pengembangan Karier terhadap Kinerja PNS pada PemKab Tabalong di Tanjung Kalimantan Selatan”, hasil penelitian menunjukkan bahwa disiplin kerja,motivasi kerja dan pengembangan karir berpengaruh positif secara baik secara simultan maupun secara parsial pada kinerja pegawai negeri sipil.

Dalam permasalahan di atas, pimpinan Notaris di Panam menjadi penentu terciptanya lingkungan kerja yang kondusif.
Gaya kepemimpinan, motivasi kerja, dan disiplin kerja merupakan faktor yang sangat mempengaruhi kinerja pegawai. Semakin baik gaya kepemimpinan, semakin tinggi tingkat motivasi kerja, dan semakin disiplin pegawai dalam melakukan pekerjaannya, maka kinerja pegawai akan semakin meningkat. Sebaliknya, semakin buruk dan tidak efektifnya gaya kepemimpinan, tidak adanya motivasi kerja, dan semakin menurunnya disiplin kerja maka kinerja pegawai akan semakin menurun.

Manajemen sumber daya manusia mempunyai beberapa fungsi-fungsi tersendiri. Dimana fungsi-fungsi tersebut saling terkait satu sama lain, serta aktivitasaktivitas yang dijalankan oleh manajemen sumber daya manusia bisa meningkatkan kinerja, produktivitas, kualitas kerja dan pelayanan.

Dalam kasus diatas untuk meningkatkan kinerja pegawai dipadukan beberapa variabel diantaranya gaya kepemimpinan, motivasi kerja dan disiplin terhadap kinerja pegawai.

Dari uraian di atas, penulis tertarik untuk melakukan suatu penelitian dengan memilih judul "Pengaruh Gaya Kepemimpinan, motivasi kerja, dan disiplin kerja terhadap kinerja karyawan Notaris" 


\section{METODE PENELITIAN}

Penelitian skripsi ini dilakukan di Kantor Notaris/PPAT yang beralamat di Panam, Pekanbaru - Riau. Populasi adalah wilayah generalisasi yang terdiri atas obyek/ subyek yang mempunyai kualitas dan karakteristik tertentu yang ditetapkan oleh peneliti untuk dipelajari dan kemudian ditarik kesimpulannya, (Sugiyono, 2006:72). Adapun yang menjadi populasi dalam penelitian ini adalah semua karyawan tetap yang berkerja di Kantor Notaris yang ada disekitaran kawasan Panam - Riau yaitu sebanyak 71 orang. Sampel adalah bagian dari jumlah dan karakteristik yang dimiliki oleh populasi.Apa yang dipelajari dari sampel, kesimpulannya akan dapat diberlakukan untuk populasi, (Sugiyono, 2006:73). Seluruh populasi dalam penelitian ini dijadikan sebagai sampel, metode ini disebut juga dengan metode sensus. penulis menggunakan data subjek, yakni berupa respon tertulis dari responden berkaitan dengan butir-butir pertanyaan atau pernyataan yang dielaborasi dari masingmasing indikator pada setiap variabel. Untuk itu, sumber data penelitian ini adalah sumber data primer. Untuk data yang biasa dilakukan wawancara dengan responden.

\section{Teknik Pengumpulan}

Teknik pengumpulan data yang digunakan untuk memperoleh data yang dijadikan bahan dalam penelitian ini, yaitu:

a. Melalui interview atau wawancara, dimana penulis mengadakan tanya jawab dengan pimpinan kantor Notaris/PPAT yang ada sekitaran Panam untuk memperoleh data perusahaan yang diperlukan dalam pembahasan skripsi. Penulis juga mengadakan wawancara dengan karyawan untuk memperoleh informasi atau data tambahan yang diperlukan dalam penelitian ini.

b. Melalui angket (kuesioner), Kuesioner merupakan teknik pengumpulan data yang dilakukan dengan cara memberi seperangkat pernyataan tertulis kepada responden untuk dijawabnya.Kuesioner yang digunakan oleh peneliti sebagai instrumen penelitian, metode yang digunakan adalah dengan kuesioner tertutup. Penulis menyiapkan daftar pernyataan yang akan diajukan kepada para karyawan di kantor Notaris/PPAT yang ada sekitaran Panam untuk memperoleh data yang digunakan dalam pembahasan skripsi.

Melalui Studi pustaka, Bertujuan untuk melengkapi kekurangan-kekurangan yang terjadi dalam pengumpulan data yang berhubungan dengan teori-teori. Analisis data yang digunakan penulis, yaitu metode deskriptif kualitatif yaitu menguraikan dan menejelaskan hasil dari penelitian berdasarkan data yang diperoleh dari interview atau wawancara dan kuesioner. Selanjutnya, digunakan metode Analisis Regresi Linear Berganda untuk mengetahui hubungan dan pengaruh antara variabel independen terhadap variabel dependen.

\section{Uji Hipotesis}

Setelah melakukan pengujian normalitas dan pengujian asumsi klasik, langkah selanjutnya yaitu melakukan pengujian atas hipotesis $1(\mathrm{H} 1)$, hipotesis 2 (H2) dan hipotesis 3 (H3). Pengujian tingkat signifikan (Test Of Significance) merupakan suatu prosedur untuk mengetahui dimana hasil sampel digunakan dalam pengujian hipotesis. Alat analisis yang dapat digunakan yaitu uji $\mathrm{F}$, koefisien determinasi $\left(\mathrm{R}^{2}\right)$ dan uji t. Perhitungan tersebut signifikan secara statistik apabila berada dalam daerah Ho ditolak.

\section{Uji F (Overall significance test)}

Uji $\mathrm{F}$ digunakan untuk mengetahui apakah variabel-variabel independen secara simultan berpengaruh signifikan terhadap variabel dependen. Derajat kepercayaan yang digunakan adalah 0,05 . Apabila nilai $\mathrm{F}$ hasil perhitungan lebih besar daripada nilai $\mathrm{F}$ menurut tabel maka hipotesis alternatif, yang menyatakan bahwa semua variabel independen secara simultan berpengaruh 
signifikan terhadap variabel dependen, dasar pengambilan keputusan adalah sebagai berikut:

Ho $: p=0 \quad$ Gaya Kepemimpinan, Motivasi Kerja dan Disiplin Kerja tidak berpengaruh simultan terhadap kinerja karyawan

Ha $: p \neq 0 \quad$ Gaya Kepemimpinan, Motivasi Kerja dan Disiplin Kerja berpengaruh simultan terhadap kinerja karyawan

a. Jika probabilitas $>$ tingkat signifikan maka Ha ditolak dan Ho diterima

b. Jika probabilitas < tingkat signifikan maka Ha diterima dan Ho ditolak

\section{Koefisien Determinasi $\left(\mathbf{R}^{2}\right)$}

Nugroho (2005:50) menyatakan bahwa koefisien determinasi $\left(\mathrm{R}^{2}\right)$ bertujuan untuk mengetahui seberapa besar kemampuan variabel independen menjelaskan variabel dependen. Jadi, pada penelitian ini koefisien determinasi digunakan untuk mengetahui kemampuan seluruh variabel independen menjelaskan kinerja karyawan. Untuk regresi linier berganda sebaiknya digunakan R Square yang sudah disesuaikan (Adjusted R Square). Nilai
R Square dikatakan baik jika di atas 0,5 karena nilai R Square berkisar antara 0 sampai 1 (Nugroho, 2005:51).

Apabila koefisien determinasi semakin mendkati satu, maka dapat dikatakan bahwa variabel independent berpengaruh terhadap variabel dependent. Selain itu koefisien determinasi dipergunakan untuk mengetahui persentase perubahan variabel terikat (Y) yang disebabkan oleh variabel $(\mathrm{X})$.

\section{Uji T ( Partial individu test)}

Uji $\mathrm{T}$ digunakan untuk mengetahui apakah variabel-variabel independen secara parsial berpengaruh nyata atau tidak terhadap variabel dependen. Derajat signifikansi yang digunakan adalah 0,05 .

\section{HASIL DAN PEMBAHASAN}

Setelah data yang telah diolah dinyatakan valid dan reliabel maka dilanjutkan dengan analisis regresi berganda dan uji hipotesis. analisis regresi linear berganda untuk mengetahui besarnya pengaruh variabel gaya kepemimpinan, motivasi kerja dan disiplin kerja terhadap kinerja pegawai

Tabel 2

Uji Regresi Linear Berganda Coefficients $^{\mathrm{a}}$

\begin{tabular}{|c|c|c|c|c|c|c|}
\hline \multirow{3}{*}{ 更 } & \multirow{3}{*}{ Model } & \multirow{3}{*}{\multicolumn{3}{|c|}{$\begin{array}{l}\begin{array}{c}\text { Standardiz } \\
\text { ed } \\
\text { Coefficient } \\
\quad \text { s }\end{array} \\
\text { Beta }\end{array}$}} & \multirow{3}{*}{$\mathbf{T}$} & \multirow{3}{*}{ Sig. } \\
\hline & & & & & & \\
\hline & & & & & & \\
\hline \multirow{4}{*}{1} & (Constant) & 3,248 & 0,561 & & 5,786 & 0,000 \\
\hline & $\begin{array}{l}\text { X1 : Gaya } \\
\text { Kepemimpinan }\end{array}$ & 0,387 & 0,086 & 0,475 & 4,515 & 0,000 \\
\hline & X2 : Motivasi Kerja & $-0,192$ & 0,094 & $-0,214$ & $-2,045$ & 0,045 \\
\hline & X3 : Disiplin Kerja & $-0,046$ & 0,091 & $-0,053$ & $-0,507$ & 0,614 \\
\hline
\end{tabular}

R Square $=0,236$

Sumber: Hasil Olahan 2018

Dari tabel di atas, maka persamaan regresi linear berganda dalam penelitian ini adalah $: \mathrm{Y}=3,248+0,387-0,192$ 0,046 


\section{Uji Simultan (Uji F)}

Untuk menguji hipotesis penelitian ini yang menyatakan bahwa Gaya Kepemimpinan, Motivasi Kerja dan Disiplin Kerja secara simultan memiliki pengaruh yang signifikan terhadap kinerja pegawai, maka perlu dilakukan pengujian secara simultan atau uji F. Model hipotesis yang diajukan antara lain:

Ho: $\mathrm{p}=0$ Gaya Kepemimpinan, Motivasi Kerja dan Disiplin Kerja tidak berpengaruh simultan terhadap kinerja karyawan

Ha: $p \neq 0$ Gaya Kepemimpinan, Motivasi Kerja dan Disiplin Kerja berpengaruh simultan terhadap kinerja karyawan

c. Jika probabilitas $>$ tingkat signifikan maka Ha ditolak dan Ho diterima

d. Jika probabilitas < tingkat signifikan maka Ha diterima dan Ho ditolak

Tabel 3

Uji Simultan ( Uji F)

ANOVA $^{\mathrm{b}}$

\begin{tabular}{ccccccc}
\hline \multicolumn{1}{l}{ Model } & $\begin{array}{c}\text { Sum of } \\
\text { Squares }\end{array}$ & Df & $\begin{array}{c}\text { Mean } \\
\text { Square }\end{array}$ & F & Sig. \\
\hline 1 & Regression & 1,734 & 3 & 0,578 & 8,210 &, $000^{\text {a }}$ \\
& Residual & 4,716 & 67 & 0,070 & & \\
& Total & 6,449 & 70 & & & \\
\hline
\end{tabular}

Sumber : Hasil olahan 2018

Dari hasil pengujian secara simultan, diperoleh hasil $\mathrm{F}_{\text {hitung }}$ adalah 8,210 sedangkan nilai $\mathrm{F}_{\text {tabel }}$ adalah 2,741 . Hal ini berarti $F_{\text {hitung }}>F_{\text {tabel }}$ dan nilai Sig $0,000<$ alpha 0,05 . Jadi dengan demikian maka $\mathrm{H}_{0}$ ditolak dan $\mathrm{H}_{1}$ diterima artinya gaya kepemimpinan, motivasi kerja dan disiplin kerja secara silmutan berpengaruh terhadap kinerja pegawai.
Uji T

Uji t digunakan untuk mengetahui pengaruh secara parsial variabel independent (gaya kepemimpinan, motivasi kerja, disiplin kerja) terhadap variabel dependen (kinerja pegawai). Berikut akan dijelaskan pengujian masing-masing variabel secara parsial.

\section{Tabel 4}

Hasil Uji t

\begin{tabular}{llllll}
\hline Hipotesis & Pernyataan & t hitung & t tabel & Sig & Keterangan \\
\hline H1 & $\begin{array}{l}\text { Gaya kepemimpinan } \\
\text { berpengaruh terhadap } \\
\text { kinerja pegawai }\end{array}$ & 4,515 & 1,996 & 0,000 & $\begin{array}{l}\text { Signifikan } \\
\text { Motivasi kerja } \\
\text { berpengaruh terhadap } \\
\text { kinerja pegawai }\end{array}$ \\
$\begin{array}{l}\text { Disiplin kerja } \\
\text { berpengaruh terhadap } \\
\text { kinerja pegawai }\end{array}$ & $-2,045$ & 1,996 & 0,045 & $\begin{array}{l}\text { Tidak Berpengaruh dan } \\
\text { Signifikan }\end{array}$ \\
& $-0,053$ & 1,996 & 0,614 & Tidak Berpengaruh dan \\
H3 & & & & & \\
\hline
\end{tabular}

Sumber: Data Olahan 2018 


\section{Pembahasan Hasil Penelitian}

Sebagaimana yang telah diuraikan sebelumnya bahwa penelitian ini adalah untuk mengetahui pengaruh gaya kepemimpinan, motivasi kerja dan disiplin kerja terhadap kinerja pegawai. Dengan demikian pembahasan yang telah dilakukan adalah untuk melihat signifikasi kontribusi pengaruh kepemimpinan, motivasi kerja dan disiplin kerja terhadap kinerja pegawai.

Berdasarkan hasil uji Determinasi $\left(\mathrm{R}^{2}\right)$ terbukti bahwa variabel gaya kepemimpinan $\left(\mathrm{X}_{1}\right)$, motivasi kerja $\left(\mathrm{X}_{2}\right)$ dan disiplin kerja secara bersama-sama berpengaruh cukup besar terhadap kinerja pegawai pada kantor notaris yang ada di sekitar Panam, sedangkan sisanya dipengaruhi oleh variabel lain yang bisa saja berupa adanya pekerjaan yang menarik dan memberi harapan, kondisi kerja, gaji, status, atau keamanan kerja, faktor lain ini sesuai dengan pendapat Sinungan (2003:140).

1. Pengaruh Gaya Kepemimpinan, Motivasi Kerja dan Disiplin Kerja Terhadap Kinerja Pegawai.

Dari hasil pengujian secara simultan, diperoleh hasil bahwa nilai $F_{\text {hitung }}$ 8,210 lebih besar dari $F_{\text {tabel }} 2,741$ dan nilai signifikan 0,000 lebih kecil dari alpha 0,05. Nilai koefisien determinasi $\left(\mathrm{R}^{2}\right)$ yang digunakan untuk menjelaskan proporsi variasi dalam variabel terikat yang dijelaskan oleh variabel bebas secara bersama-sama menunjukkan angka sebesar 0,236. Hal ini berarti bahwa variasi kinerja pegawai dijelaskan oleh gaya kepemimpinan, motivasi kerja dan disiplin kerja sebesar 23,6\%, sedangkan sebesar $76,4 \%$ dijelaskan oleh variabel lain yang tidak diteliti dalam model ini. Dari kedua pengujian diatas diperoleh kesimpulan bahwa gaya kepemimpinan, motivasi kerja dan disiplin kerja memiliki pengaruh secara simultan terhadap kinerja pegawai pada kantor notaris yang ada di sekitar Panam.
2. Pengaruh Gaya Kepemimpinan Terhadap Kinerja Pegawai

Dari hasil penelitian ini, menunjukkan bahwa gaya kepemimpinan berpengaruh dan signifikan terhadap kinerja karyawan sebesar 4,515 dengan 0,000 pada angka signifikan.Ini merupakan faktor yang dianggap setuju oleh responden mengenai faktor untuk meningkatkan kinerja pegawai pada kantor Notaris yang ada disekitar Panam. Mendukung penelitan sebelumnya yang dilakukan oleh Hapid dan Acep Rochmat Sunarwan (2014) membuktikan bahwa gaya kepemimpinan memiliki pengaruh yang paling kuat terhadap kinerja karyawan pada Kantor Notaris Panam.

\section{Pengaruh Motivasi Kerja Terhadap Kinerja Pegawai \\ Hasil pengujian menunjukkan bahwa nilai $t_{\text {hitung }}$ untuk variabel seleksi -2,045 lebih kecil dari $t_{\text {tabel }} 1,996$ atau nilai signifikan 0,045 lebih kecil dari alpha 0,05 . Hal ini berarti bahwa motivasi kerja tidak berpengaruh dan signifikan terhadap kinerja pegawai. Tidak senada dengan Bryan Johannes Tamp (2014) bahwa gaya kepemimpinan dan motivasi kerja berpengaruh positif terhadap kinerja karyawan.}

\section{Pengaruh Disiplin Kerja Terhadap Kinerja Pegawai \\ Hasil pengujian menunjukkan bahwa} nilai $t_{\text {hitung }}$ untuk variabel seleksi -0,053 lebih kecil dari tabel 1,996 atau nilai signifikan 0,615 lebih besar dari alpha 0,05. Hal ini berarti bahwa disiplin kerja tidak berpengaruh dan tidak signifikan terhadap kinerja pegawai. Penelitian ini tidak sejalan dengan penelitian terdahulu yang dilakukan oleh Harlie (2011) membuktikan bahwa disiplin kerja dan pengembangan karir berpengaruh positif secara baik dan simultan terhadap kinerja pegawai. 


\section{PENUTUP}

\section{Simpulan}

Berdasarkan analisa data dan pembahasan yang telah diuraikan dalam bab sebelumnya, maka kesimpulan yang bisa diambil dari penelitian ini adalah sebagai berikut :

1. Secara Parsial

Gay a ke pemimpinan berpengaruh dan signifikan terhadap kinerja karyawan pada kantor notaris yang ada di Panam, artinya terdapat hubungan yang signifikan antara gaya kepemimpinan dengan kinerja karyawan. Hal ini ditunjukkan gaya kepemimpinan dapat mempengaruhi kinerja karyawan dalam bekerja pada kantor notaris yang ada di Panam.

Motivasi Kerja tidak berpengaruh dan tidak signifikan terhadap kinerja karyawan. Motivasi kerja tidak berdampak langsung terhadap organisasi itu sendiri. Tidak signifikannya variabel ini dapat disebabkan motivasi kerja karyawan masih wajar sehingga tidak mempengaruhi kinerja dari karyawan kantor notaris yang ada di Panam.

Disiplin Kerja tidak berpengaruh namun signifikan terhadap kinerja karyawan pada kantor notaris yang ada di Panam. Hal ini menunjukan bahwa disiplin kerja tidak mempunyai hubungan secara langsung terhadap kinerja karyawan.

Dari hasil pengujian secara simultan gaya kepemimpinan, motivasi kerja dan disiplin kerja berpengaruh secara simultan terhadap kinerja karyawan di Kantor Notaris yang ada di Panam, artinya secara bersama - sama baik gaya kepemimpinan, motivasi kerja dan disiplin kerja dapat membantu meningkatkan kinerja dan loyalitas produktivitas dari karyawan.

\section{Saran}

Berdasarkan kesimpulan yang telah dilakukan diatas, sehingga saran-saran yang dapat penulis berikan yaitu:

1. Pengaruh variabel gaya kepemimpinan, motivasi kerja dan disiplin kerja masih sangat kecil terhadap kinerja karyawan, oleh karena itu bagi peneliti yang akan meneliti dengan tema yang sama, sebaiknya menambah jumlah variabel bebas (independen), agar hasil penelitian dapat lebih baik lagi dalam membuktikan hipotesis.

2. Agar hasil penelitian ini dapat digeneralisasi, sebaiknya penelitian yang akan datang meneliti semua kantor notaris dengan periode pengamatan yang lebih panjang.

3. Bagi peneliti selanjutnya yang berminat dengan tema yang sama dengan penelitian ini disarankan untuk menggunakan metode pengambilan sampel yang lain dengan jumlah sampel yang lebih besar, dan dapat juga diteliti apakah variable gaya kepemimpinan, motivasi kerja dan disiplin kerja berpengaruh terhadap kinerja pegawai atau produktifitas kerja, maupun kepuasan kerja yang diaplikasikan pada organisasi lain selain organisasi yang bergerak dibidang kemasyarakatan.

\section{DAFTAR PUSTAKA}

Abdila. (2011). Analisis Pengaruh Gaya Kepemimpinan Dan Motivasi Kerja Terhadap Kinerja Karyawan (Studi Pada Karyawan Badan Kesatuan Bangsa Politik Dan Perlindungan Masyarakat Provinsi Jawa Tengah).

Aditya, Ig. Dodiet. Handout : "Metodologi Research" Untuk Prodi D III Kebidanan Poltekkes Surakarta. Semester V Tahun Akademik 2008 / 2009.

Aditya Reza, Regina. (2010). Pengaruh Gaya 
Kepemimpinan, Motivasi, dan Disiplin Kerja Terhadap Kinerja Karyawan PT Sinar Santosa Perkasa. Skripsi. Semarang : Universitas Diponogoro.

Arikunto, Suharsimi. (2006). Prosedur Penelitian Suatu Pendekatan Praktik.

Edisi revisi-VI, Cetakan ke-13, Jakarta: PT. Renika Cipta,

Bangun, Wilson. (2012). Manajemen Sumber

Daya Manusia. Jakarta: Penerbit Erlangga.

Bejo, Siswanto. (2005). "Manajemen Tenaga

Kerja Indonesia pendekatan

Administratif dan Operasional”.

Jakarta : Bumi Aksara

Dedhitama Yudi. (2009). Pengaruh Motivasi Kerja dan Disiplin Kerja Terhadap Knerja Karyawan (Studi Pada Karyawan di Pabrik Gula Madukismo).

Guritno, Bambang dan Waridin. (2005). Pengaruh Persepsi Pegawai Mengenai Perilaku Kepemimpinan, Kepuasan Kerja Dan Motivasi Terhadap Kinerja. JRBI. Vol 1. No 1. Hal. 63-74.

Handoko, Hani T, Dr.MBA dan Reksohadiprodjo Sukanto, Dr. M.Com. (1996). Organisasi Perusahaan. Edisi kedua Yogyakarta : BPFE

Hasibuan, Malayu S.P. (2008). Manajemen Sumber Daya Manusia. Jakarta : Penerbit Bumi Aksara.

Hapid dan Acep Rochmat Sunarwan. (2014). Pengaruh Gaya Kepemimpian, Motivasi dan Disiplin Kerja terhadap Kinerja Karyawan PT. Financia Multi Finance Palopo. Jurnal Ekonomi Pembangunan, Vol .01 No . 02 Juli 2014

Harlie, M. (2012). Pengaruh Disiplin Kerja, Motivasi dan Pengembangan Karier terhadap Kinerja PNS pada PemKab
Tabalong di Tanjung Kalimantan Selatan.Jurnal Aplikasi Manajemen Vol. 10, No. 4,Desember 2012 : 860-867.

Ishak, Arep dan Hendri Tanjung. (2004). Manajemen Motivasi. PT. Gramedia Widiasarana Indonesia, Jakarta.

Kartono, Kartini. (2004). Pemimpin Dan Kepemimpinan. Rajawali. Jakarta.

Masrukhin dan Waridin. (2004). Pengaruh Motivasi Kerja, Kepuasan Kerja, Budaya Organisasi Dan Kepemimpinan Terhadap Kinerja Pegawai. EKOBIS. Vol 7. No 2. Hal. 197-209.

Nazir, Mohammad. (2005). Metode Penelitian. Cetakan ke-6, Bogor : Ghalia Indonesia,

Nurlaila. (2010). Manajemen Sumber Daya Manusia I. Penerbit LepKhair.

Octaviana. Ariefiantoro. (2011). Pengaruh Motivasi Kerja, Kepemimpinan, Dan Lingkungan Kerja Terhadap Kinerja Karyawan (Studi Kasus Pada Karyawan Kontraktor PT. Wineh Pandawangi Semarang ). Artikel Fakultas Ekonomi Universitas Semarang. Tanggal akses 20 $\mathrm{N}$ o v e m b e r $\quad 2016$. http://journal.usm.ac.id/jurnal/dinami ka-manajemen/236/detail/

Pramono. (2011). Pengaruh Kompensasi, Motivasi, Lingkungan Kerja dan Kepemimpinan Terhadap Kinerja Karyawan PT. Adi Mitra Pratama Semarang. Artikel Fakultas Ekonomi Universitas Semarang. Tanggal akses $25 \mathrm{~N}$ o v e m b e r 2016. http://journal.usm.ac.id/jurnal/dinami ka-manajemen/330/detail/

Prasetyo. Lis. Pengaruh Gaya Kepemimpinan Terhadap Kinerja., Jurnal Neo-Bisnis, Vol 2, No.2, Desember 2008.

Prawira, gede. (2008). "Pengaruh Disiplin 
kerja, Gaya Kepemimpinan, Dan Motivasi Kerja, Terhadap Kinerja Karyawan Pada Hotel Matahari Terbit Bali Tanjung Benoa-Nusa Dua".Skripsi.UNUD.Bali.

Ratna Kusumawati. (2008). Analisis Pengaruh Budaya Organisasi dan Gaya Kepemimpinan Terhadap Kepuasan Kerja Untuk Meningkatkan Kinerja Karyawan. Htm 1 Http://Jurnal-Sdm.Blogspot

Reza, Regina. (2010). “ Pengaruh Gaya Kepemimpinan, Motivasi dan Disiplin Kerja Terhadap Kinerja Karyawan PT Sinar Santosa Perkasa Banjarnegara". Skripsi. UNDIP: Semarang.

Rivai, Veithzal. (2004). Manajemen Sumber Daya Manusia Untuk Perusahaan. PT RAJAGRAFINDO PERSADA. Jakarta

Rumondor, Rommy Beno. (2016). Pengaruh Kepemimpinan, Motivasi, dan Disiplin Kerja terhadap Kinerja Pegawai pada Kanwil DITJEN Ke k a y a a n N e g a r a SULUTTENGGOMALUT. Jurnal EMBA Vol.4 No.2 Juni 2016, Hal. 254-264

Rutoto, Sabar. (2007). Pengantar Metedologi Penelitian. FKIP: Universitas Muria Kudus

Saryono. (2011). Metodologi Penelitian Kesehatan. Cetakan ke-4, Yogyakarta : Mitra Cendekia Press,
Setiyawan. (2006). Pengaruh Disiplin Kerja Karyawan Dan Budaya Organisasi Terhadap kinerja. Semarang. JRBI. Vol 2. No 2. Hal: 181-198.

Sudarmo, Hendika Swasti Lukita, Pengaruh Gaya Kepemimpinan, Motivasi, Dan Disiplin Kerja Terhadap Kinerja Karyawan PT. Empat Enam Jaya Abadi Balikpapan. Jurnal Sains Terapan No. 1 Vol. 2.

Sundari. (2014). "Pengaruh Motivasi dan Disiplin Kerja Terhadap Kinerja Pegawai Kecamatan Cerme Kabupaten Gresik”. Skripsi. Universitas Wijaya Putra: Surabaya.

Setiyawan, Budi dan Waridin. (2006). Pengaruh Disiplin Kerja Karyawan Dan Budaya Organisasi Terhadap Kinerja Di Divisi Radiologi RSUP Dokter Kariadi Semarang. JRBI. Vol 2. No 2. Hal: 181-198.

Sugiyono. (2011). Metode Penelitian Kuantitatif, Kualitatif, dan $R \& D$. Bandung: AFABETA, cv.

Tampi, Bryan Johannes. (2014). Pengaruh Gaya Kepemimpinan dan Motivasi terhadap Kinerja Karyawan pada PT. Bank Negara Indonesia, Tbk (Regional Sales Manado. Journal "Acta Diurna" Volume III. No.4. Tahun 2014

Thoha. (2010). Kepemimpinan dalam Manajemen, Jakarta: PT Raja Grafindo Persada.hal.49-50) 